\title{
Latest Ordovician-early Silurian palaeoenvironmental changes and palaeotemperature trends indicated by stable carbon and oxygen isotopes from northern Estonia
}

\author{
Bilal Gul, Leho Ainsaar and Tõnu Meidla \\ Department of Geology, University of Tartu, Ravila 14a, 50411 Tartu, Estonia; tonu.meidla@ut.ee, leho.ainsaar@ut.ee, bilal.gul@ut.ee
}

Received 1 April 2021, accepted 12 October 2021, available online 15 November 2021

\begin{abstract}
Brachiopods are the biological constituents most often used for the delineation of stable $\mathrm{C}$ and $\mathrm{O}$ isotopic compositions in Palaeozoic sediments. We present $\mathrm{C}$ and $\mathrm{O}$ isotope data for the Late Ordovician and early Silurian to evaluate the palaeotemperatures and palaeoenvironmental variability in Baltica from bulk rock and brachiopod shells. The studied carbonate rocks and fossils are well preserved in most of the localities as the area has not been affected by substantial tectonic activities or deep burial diagenesis. The $\delta^{13} \mathrm{C}$ and $\delta^{18} \mathrm{O}$ values for the samples range from $-1.5 \%$ to $5 \%$ and from $-7 \%$ to $-2 \%$, respectively. If the isotope signal reflects the original oxygen composition in sea water, the high $\delta^{13} \mathrm{C}$ and $\delta^{18} \mathrm{O}$ values could correspond to the colder episodes and vice versa. The Late Ordovician Hirnantian stable carbon isotopic excursion (HICE) is well recognized globally as an eminent glacial isotopic event and has been reported in several sections in the Baltic region. The HICE is observable in the bulk rock carbon stable isotope curves as a very clear gradual rise and a maximum confined to the upper part of the Ärina Formation (Porkuni Regional Stage) in northern Estonia. The rising interval of $\delta^{13} \mathrm{C}$ in the Ärina Formation may correspond to the early Hirnantian time interval. The peak HICE is followed by a gradual decline in the $\delta^{13} \mathrm{C}$ values in the basal beds of the Varbola Formation (Juuru Regional Stage). The bulk carbonate $\delta^{18} \mathrm{O}$ values show a prominent positive excursion in the Hirnantian interval possibly reflecting the global cooling event. The post-glacial latest Ordovician to early Silurian global warming might be responsible for the clear decreasing trend of both the $\delta^{18} \mathrm{O}_{\text {bulk }}$ and $\delta^{18} \mathrm{O}_{\text {brach }}$ values in the interval of the Juuru Regional Stage in the studied sections. Our study shows that $\delta^{18} \mathrm{O}$ values revealed from both the brachiopod and bulk rock material of marine Upper Ordovician-lower Silurian carbonates could tentatively be interpreted as reflecting the major temperature trends.
\end{abstract}

Key words: stable carbon and oxygen isotopes, Hirnantian, brachiopods, palaeotemperature, Ordovician-Silurian boundary.

\section{INTRODUCTION}

Stable isotope changes are nowadays widely employed in the study of Palaeozoic sedimentary sequences and several of the carbon isotopic excursions are acknowledged as stratigraphic markers. Stable oxygen isotopes provide a valuable means for tracking information about water temperature, precipitation and chemical composition. These isotopes could be taken as a function of original sea water palaeotemperature but the most common complicating factor here is a possibility of a depleted $\delta^{18} \mathrm{O}$ signal because of diagenetic overprinting of the primary carbonate composition. Previous studies on the stable isotopic composition of brachiopod shells from the Ordovician and Silurian carbonates in Estonia and adjacent areas suggest that shells, contrary to bulk rock, have still mostly retained their primary isotopic signals (Azmy et al.
1998; Brenchley et al. 2003; Shields et al. 2003; Trotter et al. 2008; Ainsaar et al. 2010; Rasmussen et al. 2016). Palaeoenvironmental events and stratigraphic gaps are usually recognized in the isotopic curves of the sedimentary successions and an indicative shape of the curves has been widely used for chemostratigraphic correlations (Brenchley et al. 2003).

The climatic conditions of the Ordovician differed from modern conditions. Several isolated plates were located near the equator and played an essential role in the distribution of fauna but also in metazoan evolution and extinction. High sea level was characteristic of the Sandbian and Katian. It was likely the highest level in the Palaeozoic, reaching 150-200 m higher than the presentday sea level (Haq \& Schutter 2008). These unique conditions were associated with the rapid diversification of biota during the early Middle Ordovician (Webby et al. 
2004). During the Ordovician, sea surface temperature (SST) variations revealed from oxygen isotope data of conodont bio-apatite show a general cooling trend. The indication of tropical SST $>40{ }^{\circ} \mathrm{C}$ in the lowermost Ordovician is clearly unrealistic, but higher up in the section, the lowering trend brings the SST values into a more reliable range, reaching $28-32{ }^{\circ} \mathrm{C}$ by the middle Ordovician (Trotter et al. 2008). The analysis using conodont-based $\delta^{18} \mathrm{O}_{\text {phos }}$ from Estonia suggests multiple phases of cooling, including rapid temperature decrease during the early Sandbian and a less intense cooling in the late Sandbian through the Katian (Männik et al. 2021). The Trotter et al. (2008) model is somewhat controversial and contradicts other models (e.g. Veizer et al. 2000; Servais et al. 2009), but its Middle Ordovician temperature values are similar to modern ocean temperatures.

The Late Ordovician extinction was one of the greatest in the Earth's history, associated with the loss of about $85 \%$ of all species (Bartlett et al. 2018). The Late Ordovician mass extinction of marine fauna can be divided into two discrete phases. The first phase (from Katian to early Hirnantian) was related to global cooling and the subsequent Hirnantian glaciation and sea-level drop. Due to Hirnantian glaciation, the former greenhouse environment was terminated during eustatic sea-level lowering due to fast cooling and glaciation (Finnegan et al. 2011). After the first extinction phase, the surviving species adapted to the new environmental conditions (Sheehan 2001). The second phase of extinction (mid-late Hirnantian) was tied to global warming, deglaciation and the subsequent sea-level rise and flooding of shelves (Finnegan et al. 2017). Some groups, like graptolites, were more affected during the first phase, whereas brachiopods were similarly affected during both extinction phases. It is believed that the cooling accompanied by the sea-level fall and loss of shallow marine habitats are the main reasons for the kill mechanism/biosphere collapse during the first extinction phase (Brenchley et al. 2001). The subsequent latest Ordovician-early Silurian is marked as a period of profound biosphere changes globally. The demise of the significant glaciation resulted in the widespread marine anoxia (Brenchley et al. 2001; Lu et al. 2017) and biodiversity slowly reached the pre-extinction levels (Brenchley et al. 2003).

The major Hirnantian glaciation event is accompanied by a strong positive $\delta^{13} \mathrm{C}$ event, the Hirnantian stable carbon isotope excursion - HICE (Brenchley et al. 1994; Ainsaar et al. 2010). Such a major carbon isotope excursion can either be caused by the increased thermohaline marine circulation resulting from increased organic carbon burial (Brenchley et al. 1994) or by abrupt sea-level fall that culminated in the intense weathering of carbonate platforms (with high $\delta^{13} \mathrm{C}$ ) of the low latitude area (Kump et al. 1999). The HICE was a short-lived interval (ca 2 Myr.) at the end of the Ordovician, which has attracted many researchers. Major changes in $\delta^{13} \mathrm{C}$ values were caused by the sequestration of organic carbon in the marine environment (Brenchley 1995) and are indicative of an important palaeoceanographic event. The HICE in isotopic curves has been correlated in different regions of the world, including North America and South China, based on graptolite biostratigraphy and the distribution of the Hirnantian shelly fauna (Brenchley et al. 2003; Saltzman \& Young 2005). In Baltica, the HICE represents one of the most remarkable positive $\delta^{13} \mathrm{C}$ excursions in the Palaeozoic succession and can be used for detailed correlation of sections across facies (Brenchley et al. 1994; Ainsaar et al. 2010). The HICE is truncated in many sections, due to erosion during the sea-level low, and the range in the amount of truncation of the $\delta^{13} \mathrm{C}$ excursion reflects the amount of erosion within the Hirnantian (Brenchley et al. 2003). The HICE interval is also marked by the elevated $\delta^{13} \mathrm{C}$ values in organic material, bulk rock and brachiopod carbonate (Brenchley et al. 1994, 2003; Marshall et al. 1997; Shields et al. 2003; Hints et al. 2010).

The Baltoscandian region serves as a key area for global Ordovician and Silurian palaeoenvironmental reconstruction and chemostratigraphic studies (Ainsaar et al. 2015). This study deals with stable carbon and oxygen isotope analysis of bulk rock carbonate and brachiopod material and aims to decipher palaeoclimatic and palaeoenvironmental changes during the Ordovician-Silurian transition and the postglacial developments in the Baltoscandian region. We intend to evaluate the palaeoenvironmental changes and palaeotemperature trends in Baltica based on the uppermost Ordovician-lowermost Silurian drill core and outcrop material from Estonian carbonate shelf facies and compare the results with previously obtained data from Estonian and Latvian sections.

\section{GEOLOGICAL SETTING}

Estonia lies on the southern slope of the Fennoscandian Shield where crystalline basement rocks are covered with nearly unaltered and unmetamorphosed sedimentary rocks, mostly with well-preserved fossils and only minor dolomitization. The thickness of the sedimentary rocks is gradually increasing southwards, reaching $0.8 \mathrm{~km}$ in the southwestern part of the country (Fig. 1; Puura \& Vaher 1997).

The Ordovician-Silurian Baltoscandian Palaeobasin represents an epicontinental basin which was mainly characterized by carbonate sedimentation. The area experienced a substantial climatic change during its drift towards the north, bringing it to the low southern latitudes near the equator (Cocks \& Torsvik 2005). The Middle Ordovician succession (Floian-Sandbian) is composed of cool-water 
limestones. The changes in carbonates reflect a transition from cold-water to tropical sedimentation in the Late Ordovician (early Katian). This transition was followed by major biotic and environmental changes due to the establishment of glacial conditions at high latitudes and low ocean temperatures in Estonia and adjacent areas near the end of the Ordovician (Cocks \& Torsvik 2005; Dronov et al. 2011).

Two principal facies belts that span across Estonia and adjacent areas are the North Estonian Shelf and the Livonian Basin (Fig. 1). The North Estonian facies belt is mainly characterized by various shallow-water limestones (wackestones-packstones) formed in shallow and middle ramp settings, mainly below the fair-weather wave base (Ainsaar et al. 2010). The Livonian Basin represents a deeper shelf succession where mudstones tend to dominate (Kaljo et al. 2001).

In northern Estonia, the Ordovician-Silurian boundary succession consists of the Adila, Ärina, Varbola and Tamsalu

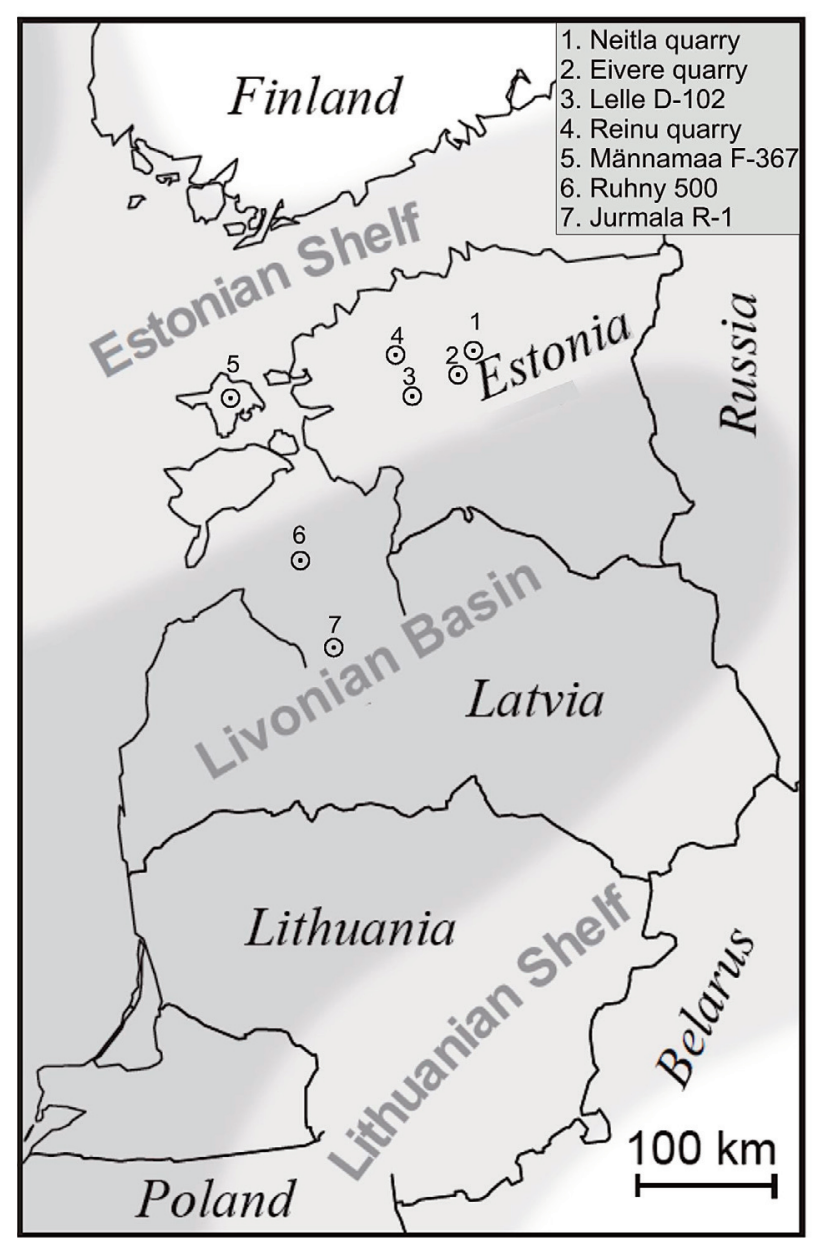

Fig. 1. Location of the study area and distribution of the Estonian Shelf and Livonian Basin (Harris et al. 2004; Radzevičius et al. 2014). formations (Fig. 2). The Adila Formation is dominated by micro- to fine-crystalline pure and argillaceous limestones (wackestones) with several discontinuity surfaces. The Ärina Formation up to $10 \mathrm{~m}$ in thickness constitutes a succession of five members (Jaanusson 1956; Kaljo et al. 1988, 2001). The lower part of the formation, the Röa Member, is represented by poorly fossiliferous dolomites that still contain some macrofossil species common with the underlying Adila Formation (Rõõmusoks 1991). The overlying Vohilaid, Siuge and Tõrevere members are comprised of a reef complex with fore-reef grainstones and back-reef bituminous carbonates. These different reef facies have been considered as separate members (Hints \& Meidla 1997), although their order in the sections may vary (Ainsaar et al. 2015). The Vohilaid Member is characterized by variegated skeletal limestones (grainstones) up to $3.7 \mathrm{~m}$ thick, but in the western part of Estonia it may also include oolitic limestones with sparry calcite (Hints \& Meidla 1997; Kaljo et al. 2001). The Siuge Member comprises up to $2.6 \mathrm{~m}$ of micro- to fine-crystalline bituminous argillaceous limestones (packstones), and the Tõrevere Member is characterized by biohermal/coral limestones with interlayers of micritic limestones containing abundant rugose corals and stromatoporoids (Kaljo et al. 2001). The reef complex is overlain by the Kamariku Member, which is formed as up to $3 \mathrm{~m}$ thick oolitic and/or sandy limestone barren of fossils.

The Varbola Formation, traditionally considered as a basal Silurian (Rhuddanian) unit in northern Estonia, is characterized by nodular argillaceous limestone (packstone) with a thickness of 10-25 m. A bed of micritic limestone (mudstone), the 0.1-3 m thick Koigi Member, is usually described at the base of the Varbola Formation. The overlying Tamsalu Formation consists of sparitic, coquinoid limestone and is subdivided into two members, Tammiku and Karinu. The Tammiku Member represents whitish to yellowish-grey massive coquinoid limestone consisting of shells and debris of the brachiopod Borealis borealis, whereas the Karinu Member consists of skeletal and peloidal grainstones (Ainsaar et al. 2014). The Raikküla Formation (topmost Rhuddanian to Aeronian, mid-Llandovery) is characterized by cyclical alternation of limestones (micritic, bioclastic, coral-stromatoporoid limestones) and lagoonal argillaceous dolomites and is widely distributed in the central and western mainland of Estonia.

\section{MATERIAL AND METHODS}

In this study, we analysed carbonate oxygen and carbon isotope data from the Adila, Ärina, Varbola and Tamsalu formations in northern and central Estonia. A total of 69 bulk rock samples from three outcrops and 142 samples 


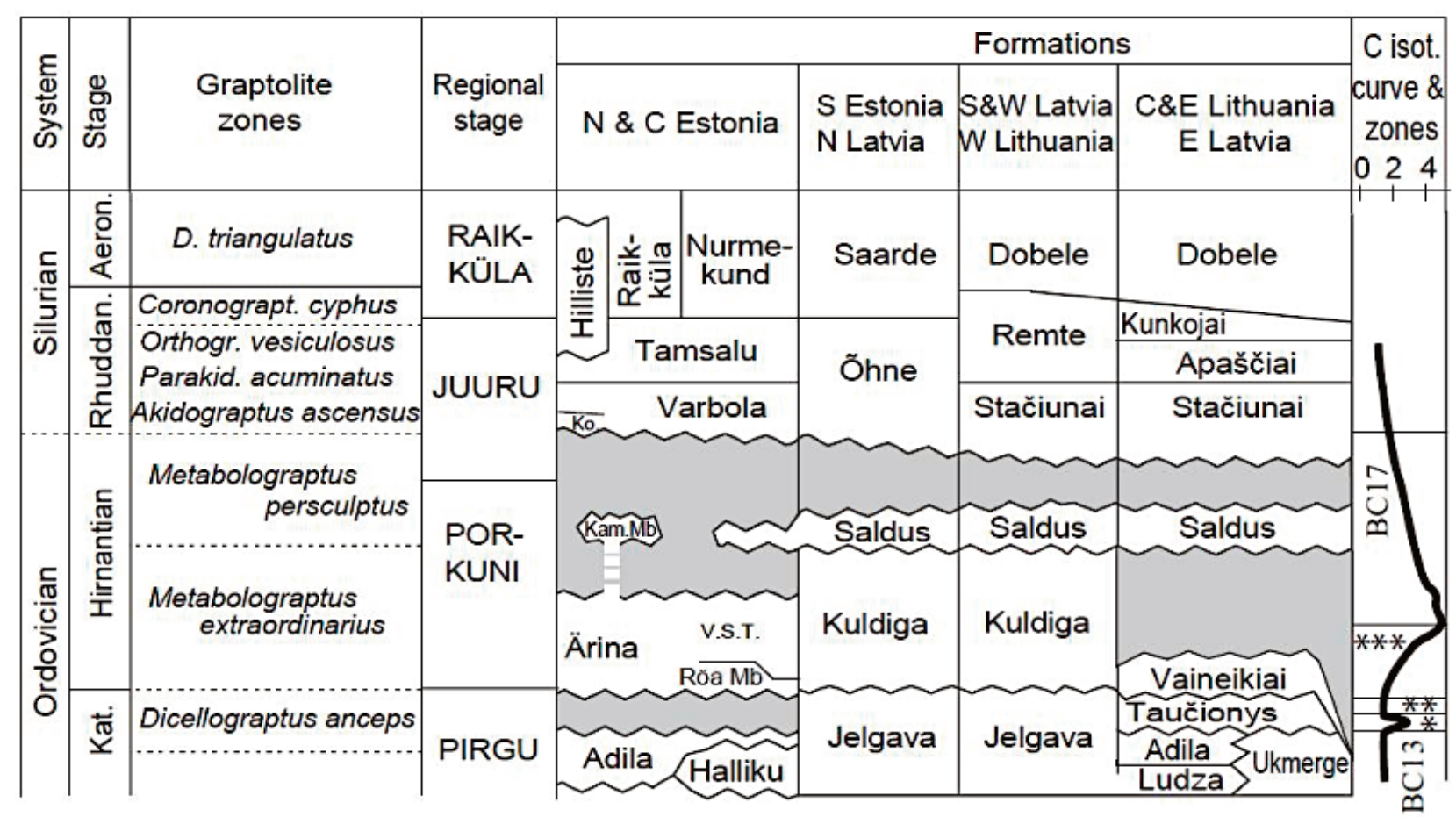

Ko.= Koigi

Kam.Mb. = Kamariku Member

$\mathrm{V} .=$ Vohilaid

$\mathrm{S}=$ Siuge

T.= Tõrevere

Fig. 2. The latest Ordovician and early Silurian stratigraphy of the Baltic region (Truuver et al. 2021).

from two drill cores were collected (supplementary data online at https://datadoi.ee/handle/33/349). The Eivere quarry (Järva County, Lat. 58.977553, Long. 25.57685) exposes lithologically distinctive argillaceous nodular packstones representing an open marine tropical carbonate shelf (Varbola Formation, $4.2 \mathrm{~m}$ ) and shallow-water highenergy carbonates (Tamsalu Formation, Tammiku Member, 4.8 m; Fig. 3). The Reinu quarry (Rapla County, Lat. 59.087299, Long. 24.73768) exposes the same distinctive lithological units in slightly different thickness (the Varbola Formation $6.85 \mathrm{~m}$ and the Tamsalu Formation, Tammiku Member 2.15 m; Fig. 3). The grey to greenishgrey limestones of the Varbola Formation alternating with thin wavy layers of greenish-grey marls are rich in fossils, with numerous stromatoporoids, corals and brachiopods. Massive occurrence of Borealis borealis is characteristic of the Tammiku Member of the Tamsalu Formation and stylolites are common.

The Neitla section is located $5 \mathrm{~km}$ east of JärvaMadise (Järva County, Lat. 59.102247, Long. 25.762486). It exposes $1.6 \mathrm{~m}$ of the shoal to open shelf carbonates of the Tõrevere and Kamariku members (Ärina Formation) and the basal Varbola Formation (Fig. 3).
The Lelle D-102 drill site is located at a crossing of the Rapla-Türi highway with the road to Lelle, in central Estonia (Lat. 58.842497, Long. 24.984431). The section characterizes the transition from shallow to deeper shelf. The core penetrates the succession from the Llandovery down to the Cambrian and demonstrates strata of variable shelf setting. In total, 122 samples at an average of three samples per metre were collected from the Lelle drill core at a depth of 61.3-104.6 m representing the interval of the Pirgu to Raikküla regional stages. The Ärina Formation in this section comprises only the Röa, Vohilaid and Kamariku members (Fig. 3). The Männamaa F-367 borehole is located in the central part of the Island of Hiiumaa (Lat. 58.83821, Long. 22.628508). In addition to the previously published isotope data (Ainsaar \& Meidla 2008), 20 samples were taken from the interval of 29.5$46.7 \mathrm{~m}$ representing the Varbola and Tamsalu formations (Fig. 3). The Lelle and Männamaa drill cores are stored at Tallinn University of Technology and the Geological Survey of Estonia, respectively.

Additionally, 25 brachiopod shells and shell fragments belonging to various orders were collected from the interval of the Varbola and Tamsalu formations in the 


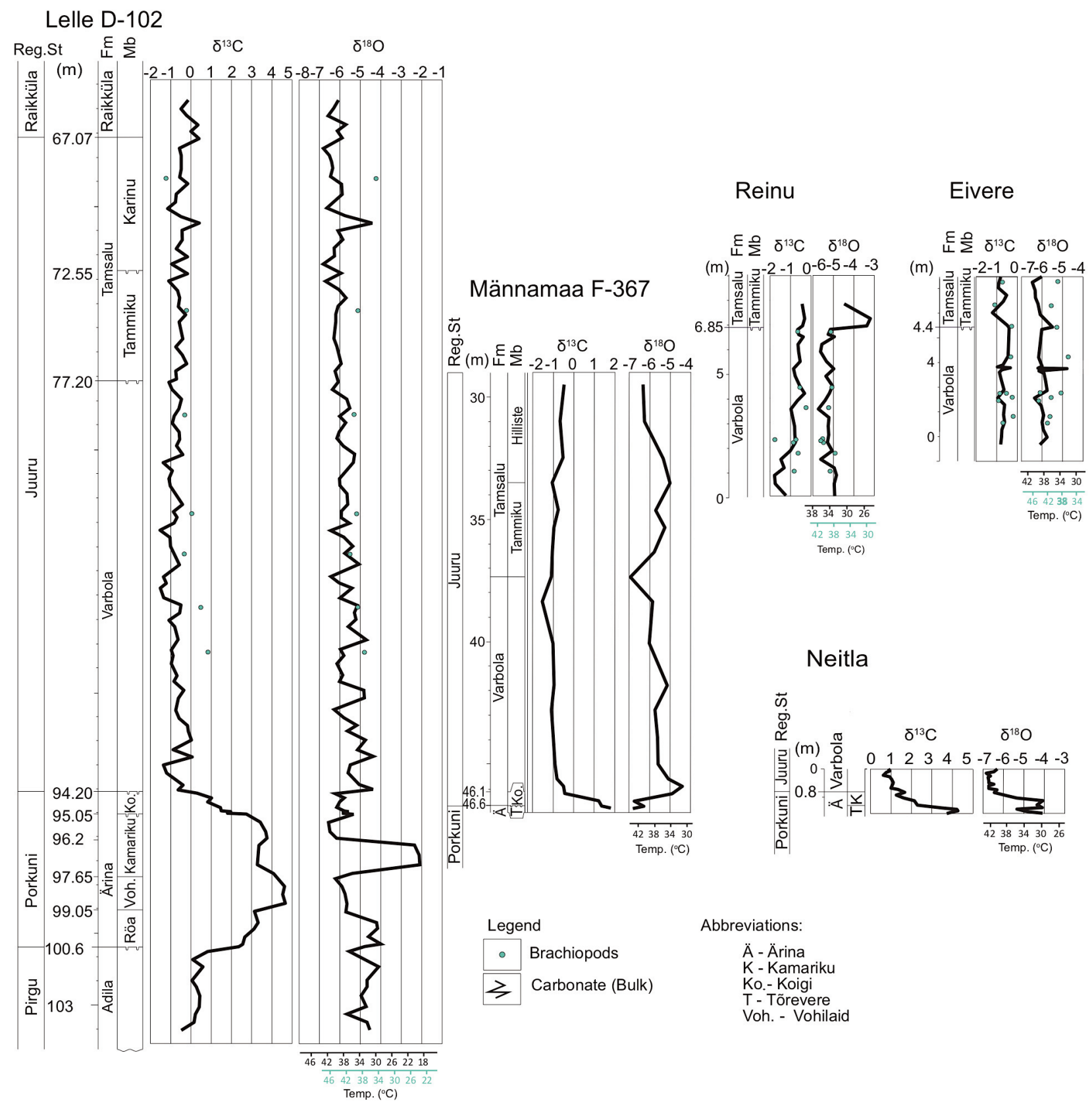

Fig. 3. The $\delta^{13} \mathrm{C}$ and $\delta^{18} \mathrm{O}$ curves of the studied sections. Circles show isotope values of brachiopod shells. Temperatures were calculated from bulk rock data by the formula of Kim \& O’Neil (1997), assuming the possible preservation of the original marine carbonate isotopic composition formed in sea water with the $\delta^{18} \mathrm{O}$ value of $-1 \%$. The temperature scale in black shows palaeotemperatures from bulk carbonate samples. As a different formula (Brand et al. 2019) was used for calculating palaeotemperature values from brachiopods, the respective temperature scale is shown in blue. Abbreviations: Reg.St, Regional Stage; Fm, Formation; Mb, Member.

Eivere and Reinu outcrops and Lelle drill core. The condition of the shells and fragments was mostly too poor for identifying families or genera, but the shell properties allowed us to distinguish between thick-shelled pentamerids (represented exclusively by Borealis borealis) and other taxa. The embedded brachiopods or shell fragments were easily exposed by breaking the rock around them and then carefully removed from the limestone matrix and cleaned. For stable isotope analyses, the brachiopod shell powder was obtained by micro-drilling avoiding cement and matrix material. The bulk rock samples were prepared (powdered) avoiding calcite veins and burrows. The 
powdered material was analysed for stable isotopes (oxygen and carbon) using a Thermo Scientific Delta V Advance continuous flow isotope ratio mass spectrometer at the Department of Geology, University of Tartu. Delta V advantage (continuous flow) + GasBench II samples were dissolved (reaction time $>8 \mathrm{~h}$ ) in $\mathrm{H}_{3} \mathrm{PO}_{4}(99 \%)$ at $25^{\circ} \mathrm{C}$. About $0.5 \mathrm{mg}$ of the powdered sample was used. The results are reported as $\delta$ notation in per mil relative to Peedee belemnite (VPDB) for both oxygen and carbon, and reproducibility of the results is generally better than $\pm 0.1 \%$ and $\pm 0.2 \%$ o for carbon and oxygen, respectively. The international laboratory standards (from IAEA) IAEA-60, NBS 18 and LSVEC were used.

\section{STABLE ISOTOPIC COMPOSITION}

\section{Carbon isotope record $\left(\delta^{13} \mathrm{C}\right)$}

Carbonate rocks are very well preserved in most localities in Estonia as the area has not been affected by pronounced tectonic activities or deep burial diagenesis during the Phanerozoic. The degree of diagenetic alteration of the isotopic composition of carbonates is often evaluated on the basis of a bulk carbonate $\delta^{13} \mathrm{C}-\delta^{18} \mathrm{O}$ cross plot (Fig. 4), as the relationships between the $\delta^{13} \mathrm{C}$ and $\delta^{18} \mathrm{O}$ values are suggested to reflect the degree of meteoric diagenesis (Jacobsen \& Kaufman 1999). The carbon and oxygen isotopic composition of the studied samples shows no clear covariation between the $\delta^{13} \mathrm{C}$ and $\delta^{18} \mathrm{O}$ values $\left(\mathrm{R}^{2}=0.0646\right.$ at Reinu, $\mathrm{R}^{2}=0.2479$ at Eivere, $\mathrm{R}^{2}=0.0385$ at Lelle, see Fig. 4) except for the very short and lithologically highly variable Neitla outcrop section $\left(\mathrm{R}^{2}=0.7573\right.$, Fig. 4$)$. The densely clustered values without extreme negative points on both axes may suggest relatively good preservation of micritic carbonate. Some overprint of the primary signal could still not be ruled out on this basis, judging from small groups of 'outlier points' of the Lelle, Neitla and Reinu sections (see Fig. 4). This indicates that the material may not be completely homogeneous in this respect.

Petrographic analyses of earlier studies (summarized by Azmy et al. 1998) show insignificant dolomitization and recrystallization. The general features of isotopic variations through time are retained.

Previous studies show that elevated $\delta^{13} \mathrm{C}$ values of carbonates of the Porkuni Regional Stage in Estonia and surrounding areas correspond to the HICE rising to a peak of up to $+7 \%$ o (Brenchley 2004; Meidla et al. 2014). The results reported from the bulk rock samples in the Lelle drill core in general show a positive excursion largely similar to that in the Tartu 453, Ruhnu 500, Männamaa and Jurmala R-1 cores (Ainsaar et al. 2010, 2015; Bauert et al. 2014) but still with some differences

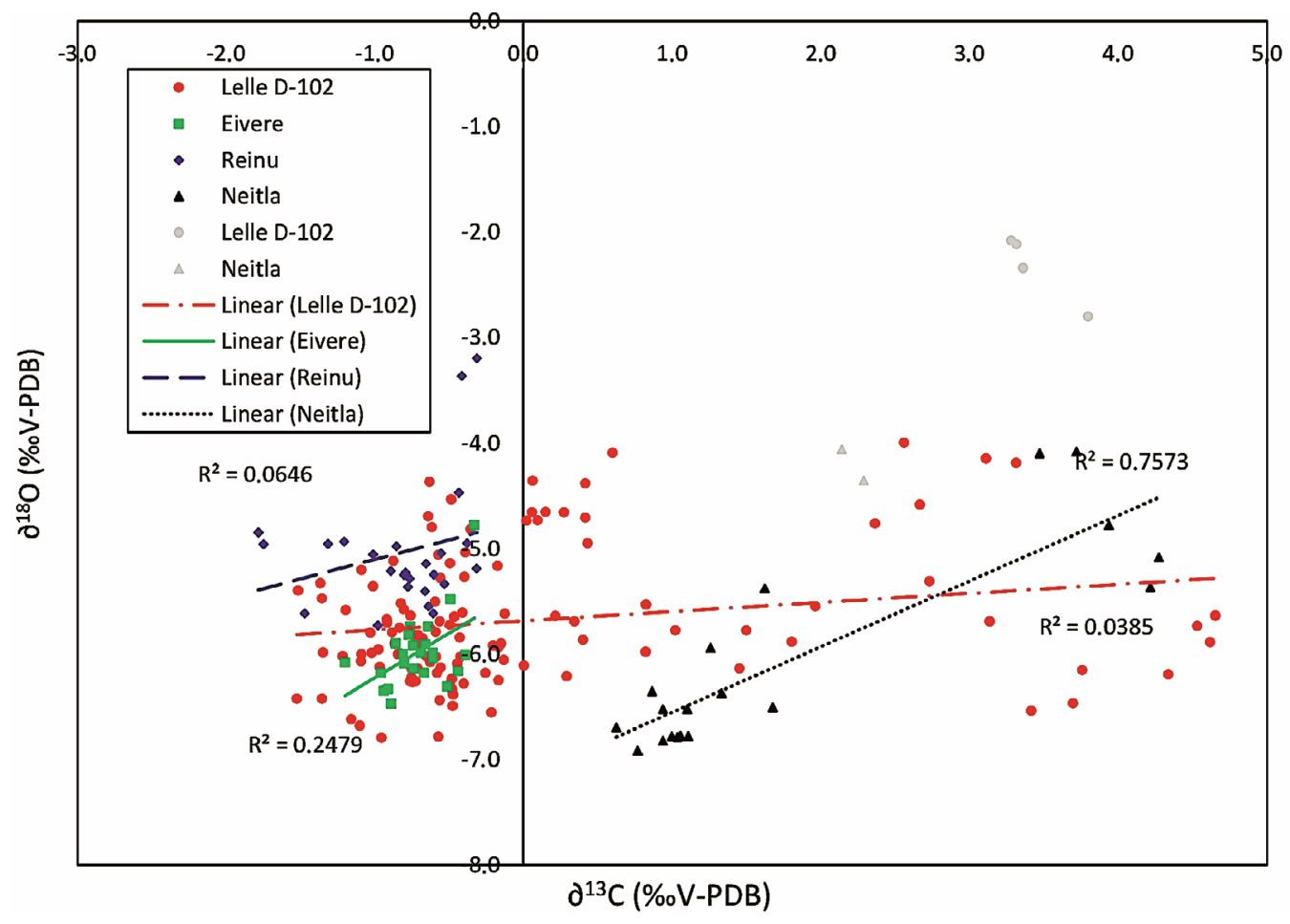

Fig. 4. Oxygen vs carbon isotopic composition measured from bulk carbonate material in the studied stratigraphic units. The light grey data points mark the likely altered samples from the Kamariku Formation and were not taken into account when calculating $\mathrm{R}^{2}$. 
likely explained by gaps in the Porkuni Regional Stage in Estonia.

The pre-HICE $\delta^{13} \mathrm{C}$ values are typically between $-0.5 \%$ and $+1 \%$ in the Estonian Shelf area (Ainsaar et al. 2015). The $\delta^{13} \mathrm{C}$ values in the Lelle section studied here show a slight increase in the upper part of the Adila Formation (from $-0.5 \%$ o to $0.8 \%$ ). The sharp rise in carbon isotopic values is tied to a discontinuous contact of the Adila and Ärina formations. The isotopic curve shows a continuous rise up to the Vohilaid Member of the Ärina Formation (from $0.8 \%$ o to $4.7 \%$ ) where the discontinuity surface at the base of the Kamariku Member probably marks a hiatus as the isotopic values drop rapidly at this level. Higher up, the values decline to $0 \%$ at the top of the Koigi Member of the Varbola Formation. Upwards from the HICE, there is a slow fall of $\delta^{13} \mathrm{C}$ values, followed by a subsequent gentle rise from the middle part of the Varbola Formation up to the top of the Tamsalu Formation, without significant peaks and fluctuations.

In the Neitla outcrop, the $\delta^{13} \mathrm{C}$ values are the highest (4.3\%o) in the sandy Kamariku Member of the Ärina Formation, as observed in the Vohilaid Member in the Lelle drill core. There is a continuous decline till the top of the Kamariku Member where the values reach 1.3\%o. The decrease in the stable carbon isotopic values continues in the basal part of the Varbola Formation, which lithologically shows some similarities to the Koigi Member. The Varbola Formation is exposed in a thickness of about $1 \mathrm{~m}$ and the values drop from $1.7 \%$ o to $0.6 \%$ within this interval. In the Eivere and Reinu quarries, the $\delta^{13} \mathrm{C}$ values from the Varbola and Tamsalu formation lie between $-1.7 \%$ and $-0.3 \%$. The difference recorded between the bulk rock and brachiopod carbon isotopic values in the Varbola and Tamsalu formations is ca $0 \%$ and 2\%o, respectively (Fig. 3).

In the Männamaa core section, the HICE is well expressed (Fig. 5; Ainsaar \& Meidla 2008; Ainsaar et al. 2010) and the falling limb of the excursion is sharply cut above the highest values because a significant stratigraphic gap has been recorded at the boundary of the Porkuni and Juuru regional stages in this area (Kaljo et al. 2001). An upward decline in $\delta^{13} \mathrm{C}$ values from $1.2 \%$ to $-0.5 \%$ is recorded in the Koigi Member and is followed by a relatively flat curve in the rest of the Varbola Formation and a gently rising trend in the Tamsalu Formation.

\section{Oxygen isotope record $\left(\delta^{18} \mathrm{O}\right)$}

The $\delta^{18} \mathrm{O}$ values in the bulk rock samples from the studied sections range from $-7 \%$ to $-4 \%$, remaining, with few exceptions, within the limits of normal unaltered values in Palaeozoic marine carbonates. Greater deviations from unaltered $\delta^{18} \mathrm{O}$ values are recorded in the Porkuni
Regional Stage. The $\delta^{18} \mathrm{O}$ values in the Adila Formation of the Lelle section range between $-5.6 \%$ and $-4.2 \%$. The boundary of the Adila and Ärina formations is marked by a change towards higher values which continue through the Röa Member but decrease in grainstones of the overlying Vohilaid Member. The $\delta^{18} \mathrm{O}$ values increase markedly in the lower part of the sandy Kamariku Member, ranging between $-5.4 \%$ and $-2.1 \%$. Several abrupt changes in $\delta^{18} \mathrm{O}$ values between the depths of 95.5 and $100.6 \mathrm{~m}$ likely correspond to gaps in the succession. The $\delta^{18} \mathrm{O}$ values drop to $-6.8 \%$ in the topmost part of the Ärina Formation in the Lelle section. The values in the Varbola and Tamsalu formations range from $-6.8 \%$ to $-4 \%$, with a clear decreasing trend up-section.

A significant stratigraphic change in the stable oxygen isotope composition is visible in the Neitla outcrop section where the $\delta^{18} \mathrm{O}$ values drop from $-4 \%$ in the topmost Ärina Formation to $-7 \%$ in the basal Varbola Formation (Fig. 3). The $\delta^{18} \mathrm{O}$ values for the Varbola and Tamsalu formations in the Eivere, Reinu and Männamaa sections are in the range of $-7 \%$ to $-4 \%$, with a very gentle upward falling trend. The rise in $\delta^{18} \mathrm{O}$ values in the Varbola-Tamsalu boundary interval at Reinu may likely be due to a higher degree of dolomitization described in this interval of the quarry wall.

The stable carbon and oxygen isotopic compositions of the brachiopod shells were analysed in the Varbola and Tamsalu formations. The $\delta^{18} \mathrm{O}_{\text {brach }}$ values from the studied interval are spanning between $-6.1 \%$ and $-4.3 \%$. With few exceptions, the isotopic values of the brachiopod shells deviate from the bulk rock $\delta^{18} \mathrm{O}$ curve by less than $1 \%$, with brachiopod shells being typically isotopically heavier (Fig. 3).

\section{DISCUSSION}

\section{Carbon isotope chemostratigraphy}

Carbonate rocks retain syndepositional carbon isotope values under diagenetic recrystallization and lowgrade metamorphism (Valley \& O'Neil 1984; Hood et al. 2018). This knowledge is important for the reconstruction of environmental changes and palaeoclimate records (Brenchley et al. 2003). The Ordovician-Silurian transition is a critical interval where the widespread positive $\delta^{13} \mathrm{C}$ excursion of the Hirnantian is traced around the world (Brenchley et al. 1994, 2003; Trotter et al. 2008; Ainsaar et al. 2010; Saltzman \& Thomas 2012; Rasmussen et al. 2016). The rapid change in $\delta^{13} \mathrm{C}$ suggests a change in carbon cycling in the atmosphere, ocean and sediment system (Brenchley et al. 2003).

The results of the current study support the carbon isotope chemostratigraphic correlations of the HICE 

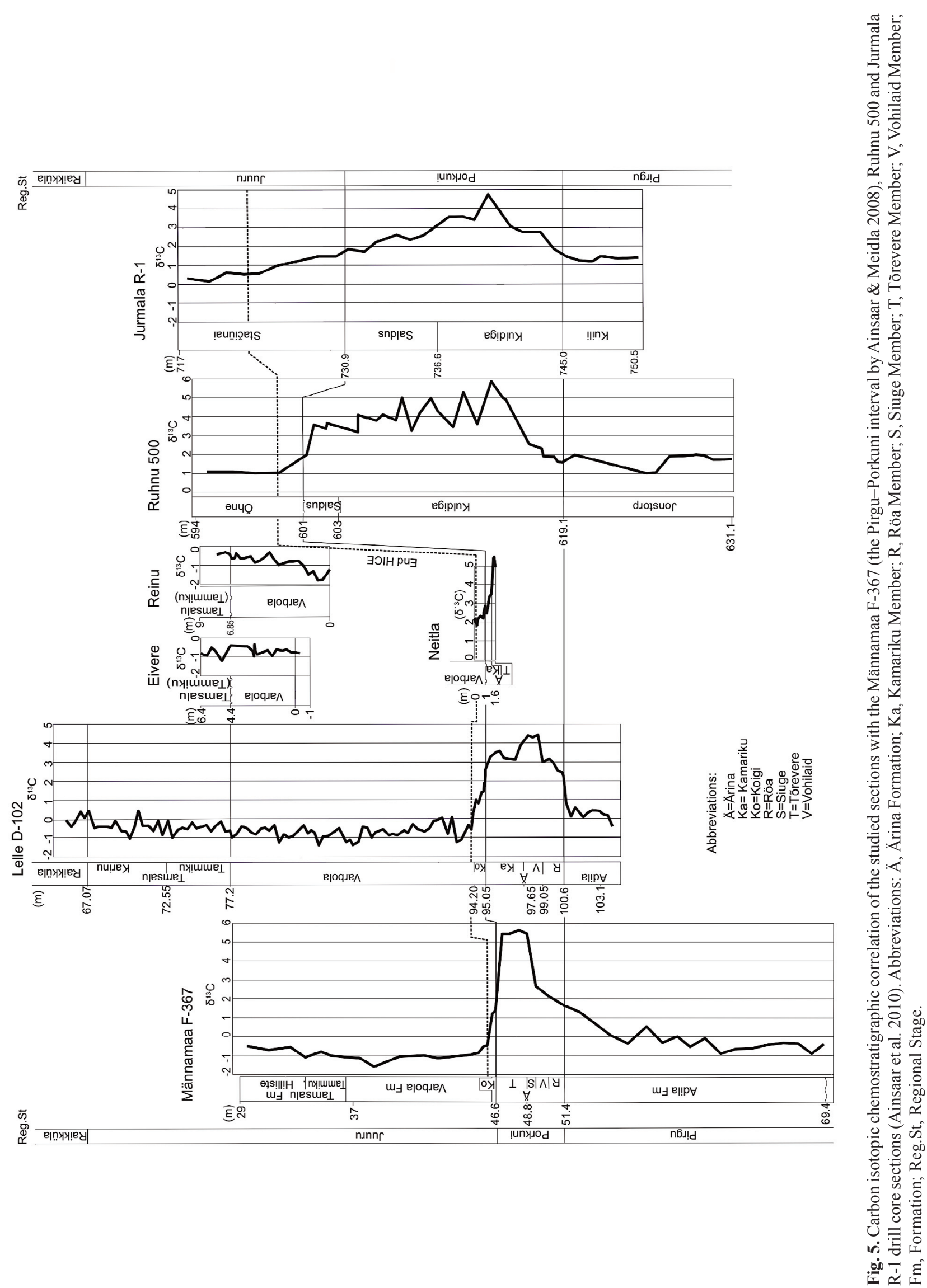
interval in Baltoscandia (Ainsaar et al. 2010) and its relation to glacioeustatic sea-level changes. The pre-HICE $\delta^{13} \mathrm{C}$ values in the Lelle, Ruhnu, Männamaa and Jurmala cores lie within a range of $-0.5 \%$ o to $+1 \%$ (Fig. 5). The sharp $\delta^{13} \mathrm{C}$ rise at the boundary of the Pirgu and Porkuni regional stages marks the base of the HICE and has been used for tracing the base of the Hirnantian in the region (Kaljo et al. 2001; Ainsaar et al. 2010). This rising pattern of $\delta^{13} \mathrm{C}$ in the HICE is similar in the Männamaa, Ruhnu and Jurmala drill cores (Fig. 5). The Ruhnu core shows the peak value of $c a 5.9 \%$ in the Kuldiga Formation and the Männamaa curve shows $\delta^{13} \mathrm{C}$ peak values up to $5.7 \%$ o in the Ärina Formation. The curve of the Männamaa core is cut sharply, which clearly marks a stratigraphic gap (Ainsaar et al. 2010). The isotope curve from the stratigraphically more complete Jurmala section of the Livonian Basin facies zone shows a similar $\delta^{13} \mathrm{C}$ rise with a peak value of $4.6 \%$ in the Kuldiga Formation (Fig. 5). The decrease in the highest $\delta^{13} \mathrm{C}$ values of the HICE offshore has been tentatively ascribed to differences in diagenetic alteration and depositional environments or to the presence of unconformities (Brenchley et al. 2003). Possible alternatives comprise the aquafacies effect (suggested by Ainsaar et al. 2019) or effects from a stratified water column (Bickert et al. 1997).

A slight decrease in $\delta^{13} \mathrm{C}$ values (from $4.7 \%$ to $3.3 \%$ ) in the Kamariku Member (Ärina Formation) in the Lelle core section is followed by a slight rise to $3.8 \%$ that is probably suggesting a stratigraphic gap in the Kamariku Member. Due to erosion or nondeposition, the Kamariku Member is missing in the Männamaa section, but a similar 'secondary' peak of the HICE was recorded also in some of the Karinu sections and in the Kamariku core by Ainsaar et al. (2015). The same authors suggested that the Kamariku Member, marking the declining limb of the HICE, might be taken as a stratigraphic equivalent to the uppermost Kuldiga and Saldus formations in the southern regions of Estonia. This suggestion is based on the fact that the Kamariku Member, represented by nonfossiliferous carbonate-cemented fine-grained quartz sand, is bound above and below by unconformities and has very different lithology from that of the underlying reef unit. The bipartite subdivision of the Kamariku Member in the Lelle drill core agrees with the previously proposed correlation.

The declining limb of the $\delta^{13} \mathrm{C}$ curve of the Lelle section terminates at the value $-0.6 \%$ near the top of the Koigi Member of the Varbola Formation. The continuation of the falling limb of the HICE in the basal beds of the Varbola Formation, Juuru Regional Stage, suggests the Hirnantian age of these beds (Ainsaar et al. 2015). The HICE reported from several sections in the Baltic region shows roughly synchronous positive $\delta^{13} \mathrm{C}$ peaks (Ainsaar et al. 2010, 2015; Gorjan et al. 2012), but the last stage of the excursion may look different (Brenchley et al. 2003; Ainsaar et al. 2010). As an example of the deep shelf environment, the falling limb $\delta^{13} \mathrm{C}$ pattern in the Jurmala section is nearly continuous, without rapid fluctuations and reaches for about $10 \mathrm{~m}$ into the strata that were formerly attributed to the Silurian (see also Meidla et al. 2020). It is therefore likely that the base of the Silurian System is located in the lower part of the Varbola Formation in northern Estonia (Bauert et al. 2014; Hints et al. 2014; Ainsaar et al. 2015) and within the Stačiūnai Formation in the Livonian Basin (Meidla et al. 2020).

The latest Ordovician and earliest Silurian are considered as the beginning of recovery from the Hirnantian glaciation, low sea levels and mass extinction. The base of the Silurian System has been set at the level of the first appearance of the graptolite species Akidograptus ascensus by an international agreement (Rong et al. 2008; Jones et al. 2011). As graptolites are not preserved in carbonate-dominated shelves, like the Estonian or US Midcontinent successions, other evidence must be used for establishing the position of the systemic boundary. For analysing the relationships between the HICE and the Ordovician-Silurian boundary, it is vital to examine the stratigraphically most complete sections where the glacioeustatic sea-level fall has least affected the depositional processes. The post-HICE (latest Hirnantian-Rhuddanian) $\delta^{13} \mathrm{C}$ values do not show distinctive trends or excursions.

In global correlation, the $\delta^{13} \mathrm{C}$ curve of the Lelle section in the HICE interval shows similarities with the Wangjiawan Riverside section, South China, where Chen et al. (2006) have documented two peaks, one in the lower Hirnantian (Normalograptus extraordinarius Biozone) and the other in the middle Hirnantian (Normalograptus persculptus Biozone), although some fluctuation in values is observed throughout the $\delta^{13} \mathrm{C}$ excursion. The rising interval of $\delta^{13} \mathrm{C}$ in the Ärina Formation between 101.15 and $97.8 \mathrm{~m}$ in the Lelle section may be correlated to the first peak in the Wangjiawan Riverside section. Similarly, the second peak at Lelle may correspond to the second peak in the basal $N$. persculptus Biozone of the Wangjiawan Riverside section. The post-glaciation anoxia was re-established as the temperature rose (Brenchley et al. 1994, 2003; Brenchley \& Marshall 1999; Sheehan 2001; Harper et al. 2014; Young et al. 2020).

\section{Oxygen isotopic data and palaeotemperature estimation}

In the current study, the $\delta^{18} \mathrm{O}$ profile values lie mostly between $-7 \%$ and $-2 \%$. The question of if and to what degree these data could be interpreted in the context of palaeotemperatures has no simple and straightforward answer. Secular variation in $\delta^{18} \mathrm{O}$ may be influenced not 
only by sea water temperature but also by a multitude of other factors, like the isotopic composition of sea water, salinity, source and composition of mud, vital effects, diagenetic alteration, etc. (Munnecke et al. 2010). Some of these factors (e.g. isotopic composition of sea water, smaller changes in salinity, source areas of mud) are difficult to evaluate, whilst trends in some others could be assumed from the analysis of rock properties and facies gradients. Brachiopods are likely a more reliable source of temperature information and the presence of the secondary layer in Baltoscandian brachiopod shells suggests that vital effects are unlikely or minor. The secondary layer is more likely formed in or near isotopic equilibrium with ambient sea water whilst the primary shell layer is not (Ullmann et al. 2017).

Baltoscandian oxygen data from brachiopods, obtained by previous studies and the current study, reflect similar trends. Pre-HICE $\delta^{18} \mathrm{O}$ brachiopod values from Estonian and Latvian sections are usually between $-3 \%$ o and $-5.5 \%$ (e.g. Brenchley et al. 1994). In the Late Ordovician Porkuni Regional Stage (Hirnantian), $\delta^{18} \mathrm{O}_{\text {brach }}$ values reflect an increase up to $-2 \%$, like in the Stirnas core (Hints et al. 2010), as well as at Ruhnu and Riekstini (Brenchley et al. 2003). Higher $\delta^{18} \mathrm{O}$ values are recorded in the Hirnantian throughout the Baltic region (Brenchley et al. 2003). The range of values in the early Silurian is similar to those observed pre-HICE, with $\delta^{18} \mathrm{O}_{\text {brach }}$ values remaining between $-4 \%$ and $-3 \%$ (Brenchley et al. 1994).

The value of palaeotemperature reconstructions for the Palaeozoic era based on $\delta^{18} \mathrm{O}$ from bulk rock is still uncertain. It remains unclear if and how much the Palaeozoic sea water $\delta^{18} \mathrm{O}$ values were subsequently altered, although similar data are considered useful in the reconstruction of palaeoconditions of the Cenozoic and Mesozoic eras (Trotter et al. 2008). Previous studies show that calculated temperatures are often unrealistic, reaching up to $70{ }^{\circ} \mathrm{C}$ for the Early Palaeozoic (Grossman 2012; Song et al. 2019).

Temperature calculations (after the formula of Kim \& O’Neil 1997 , assuming sea water $\delta^{18} \mathrm{O}$ value $-1 \%$ ) by using the bulk oxygen data from the Lelle drill core show that the pre-HICE temperatures could have ranged from ca $30{ }^{\circ} \mathrm{C}$ to $36{ }^{\circ} \mathrm{C}$. These values are higher than modern temperatures but rather close to the estimates in other papers (e.g. Grossman \& Joachimski 2020). No brachiopods suitable for analyses were collected from this interval.

Interpreting the isotopic data in temperature context reveals a temperature rise up to $37^{\circ} \mathrm{C}$ in the lower part of the Ärina Formation with the start of the HICE. This could be related to sea-level fall that likely promoted increased warming of tropical sea waters in the basin but, alternatively, it may also be related to a preservation issue of the oxygen isotopic composition in carbonate. The abrupt decline in temperature by $12-14{ }^{\circ} \mathrm{C}$ in the overlying Kamariku Member (Fig. 3), calculated from the $\delta^{18} \mathrm{O}_{\text {bulk }}$ values, looks consistent with the generally accepted Hirnantian scenarios (Brenchley et al. 2003; Trotter et al. 2008; Finnegan et al. 2011) but is too large for a tropical area, compared to the tropical sea-surface temperature changes in the Pleistocene and Holocene (about $1-3{ }^{\circ}$ C; e.g. Lea et al. 2003; Herbert et al. 2010). As the sandy Kamariku Member represents the most nearshore deposits in this succession, overprint of the primary signal seems possible and even likely, particularly considering the fact that the respective points form outlier groups in the carbonate $\delta^{13} \mathrm{C}-\delta^{18} \mathrm{O}$ cross plot (Fig. 4).

The $\delta^{18} \mathrm{O}$ values return to the pre-HICE level at the top of the Kamariku Member. The gradual negative $\delta^{18} \mathrm{O}$ trend of values through the Varbola and Tamsalu formations in the Lelle section (Fig. 3) could be interpreted as a temperature rise from about $34{ }^{\circ} \mathrm{C}$ to $40{ }^{\circ} \mathrm{C}$. This trend gains limited support from other studied sections. Some temperatures calculated from the bulk rock data of the Männamaa section in the Juuru Regional Stage (more than $44^{\circ} \mathrm{C}$ ) are clearly higher and unrealistic.

The temperature calculated from brachiopods (using the formula by Brand et al. 2019) of the Eivere and Reinu sections (Fig. 3) in the same strata are similar, ranging generally from $36^{\circ} \mathrm{C}$ to $41^{\circ} \mathrm{C}$ (occasionally up to $43{ }^{\circ} \mathrm{C}$ ), close to the brachiopod-derived temperatures in other studies (e.g. Grossman \& Joachimski 2020; Fig. 3). Isotopic values $\left(\delta^{13} \mathrm{C}\right.$ and $\left.\delta^{18} \mathrm{O}\right)$ of most brachiopod species suggest that the secondary shell layers were secreted in or near isotopic equilibrium with ambient sea water, but in some species also disequilibrium values are recorded (Ullmann et al. 2017). A trend towards an increase in brachiopod-derived temperatures is observed upwards in the Varbola Formation of the Velise section. On this background, the shells of Borealis borealis, the only and massively available brachiopods in the Tamsalu Formation, revealed isotopic values that reverse this trend. Considering these results and also an opposite linear trend of the bulk rock data, we may suggest that lower temperature values calculated from the brachiopods Borealis borealis (Pentamerida) of the Tamsalu Formation may be influenced by a vital effect. The offset of temperature values calculated from Borealis borealis is increasing in the upper Tamsalu Formation. It is well known that the primary layer is rarely found in pentamerids and the secondary layer is mostly altered and does not provide reliable data for isotope interpretations (Samtleben et al. 2001). The temperatures calculated from other brachiopods from the Juuru Regional Stage range between $\mathrm{ca} 37^{\circ} \mathrm{C}$ and $40{ }^{\circ} \mathrm{C}$, being not far from the modern tropical temperatures. Compared to the presentday temperature of sea water, the temperature values calculated from the bulk rock data of the upper Varbola to 
Raikküla formations are unrealistically high even for tropical sea surface values, but the more densely sampled Velise section is demonstrating a consistent decrease in $\delta^{18} \mathrm{O}$ values. The brachiopod calcite temperature values in the main part of the Varbola Formation seem to be in a better agreement with the warming scenario of the early Silurian. These values are also closer to modern temperatures and lower than the temperatures calculated from bulk rock data.

Nevertheless, although temperature is the critical factor controlling the oxygen isotope changes, the contribution of many other factors that are difficult to quantify, like freshwater input and ice volume changes (Trotter et al. 2016), can be substantial. The absolute temperature values calculated from our data may not be precise, but the observed trends are in a surprisingly good agreement with the general scenario of the Hirnantian glaciation event. Although this has usually not been expected, the changes in the stable oxygen isotopic values may still be meaningful and may refer to generalized climatic trends.

\section{CONCLUSIONS}

The high-resolution stable carbon isotopic data reported from the bulk carbonates of the end-Ordovician-basal Silurian interval in the Lelle D-102 drill core characterize the pre-HICE, HICE and post-HICE chemostratigraphy and palaeoenvironmental history in the Estonian Shelf of the Baltoscandian Palaeobasin. The HICE is bipartite and the upper maximum is confined to the Kamariku Member of the Ärina Formation, like also in the Neitla outcrop sections. The stratigraphic extent of the HICE in the studied sections confirms the suggestion that the base of the Silurian System is located considerably higher than the base of the Varbola Formation and that of the Juuru Regional Stage in Baltoscandia. The post-HICE $\delta{ }^{13} \mathrm{C}$ values show no distinctive isotopic peaks and only gentle trends in the Varbola and Tamsalu formations (Rhuddanian Stage).

The $\delta^{18} \mathrm{O}$ values revealed from the studied sections suggest relatively low alteration by diagenesis and the observed trends may tentatively be interpreted as reflecting the general temperature trends. The Hirnantian glaciation episode corresponds to a $\delta^{18} \mathrm{O}$ maximum (and temperature minimum) confined to the upper part of the Ärina Formation. The bulk rock oxygen isotopic data from the post-HICE lower Rhuddanian interval may suggest a rising temperature trend. Higher $\delta^{18} \mathrm{O}$ values derived from the brachiopod data of the Tamsalu Formation compared to the bulk carbonates may be due to vital effects or better preservation of pentamerid brachiopods prevailing in this interval. The study demonstrates that $\delta^{18} \mathrm{O}$ values revealed from both the brachiopod and bulk rock material of marine Upper Ordovician carbonates reveal parallel trends and may reflect general trends of sea water temperature in the intervals of well-preserved carbonate rocks.

Acknowledgements. This study was supported by Estonian Research Council grant PRG836. We are grateful to the referee Axel Munnecke, the anonymous referee and the editor-in-chief of the journal Olle Hints for constructive comments and suggestions that greatly improved the manuscript. This paper is a contribution to the IGCP project 735. The publication costs of this article were partially covered by the Estonian Academy of Sciences.

\section{Supplementary online data}

Supplementary material online can be found at https://datadoi.ee/ handle/33/349. It contains the list of all bulk rock and brachiopod samples, together with analytical results (stable carbon and oxygen isotope ratios).

\section{REFERENCES}

Ainsaar, L. \& Meidla, T. 2008. Ordovician carbon isotopes. In Männamaa (F-367) Drill Core (Põldvere, A., ed.), Estonian Geological Sections, 9, 27-29.

Ainsaar, L., Kaljo, D., Martma, T., Meidla, T., Männik, P., Nõlvak, J. \& Tinn, O. 2010. Middle and Upper Ordovician carbon isotope chemostratigraphy in Baltoscandia: a correlation standard and clues to environmental history. Palaeogeography, Palaeoclimatology, Palaeoecology, 294, 189-201.

Ainsaar, L., Männik, P. \& Meidla, T. 2014. Stop B2: Eivere quarry. In 4th Annual Meeting of IGCP 591, Estonia, 10-19 June 2014, Abstracts and Field Guide (Bauert, H., Hints, O., Meidla, T. \& Männik, P., eds), pp. 178-179. University of Tartu, Tartu.

Ainsaar, L., Truumees, J. \& Meidla, T. 2015. The position of the Ordovician-Silurian boundary in Estonia tested by highresolution $\delta^{13} \mathrm{C}$ chemostratigraphic correlation. In Chemostratigraphy: Concepts, Techniques, and Applications (Ramkumar, M., ed.), pp. 395-412. Elsevier.

Ainsaar, L., Meidla, T. \& Hints, O. 2019. Carbon isotopic composition of Ordovician carbonates in Baltoscandia: shallow marine facies shifting the $\delta^{13} \mathrm{C}_{\text {carb }}$ values in different ways. In Contributions: $13^{\text {th }}$ International Symposium on the Ordovician System, Novosibirsk, Russia, July 19-22, 2019 (Obut, O. T., Sennikov, N. V. \& Kipriyanova, T. P., eds), pp. 7-8. Publishing House of SB RAS, Novosibirsk.

Azmy, K., Veizer, J., Bassett, M. G. \& Copper, P. 1998. Oxygen and carbon isotopic composition of Silurian brachiopods: implications for coeval sea water and glaciations. Geological Society of America Bulletin, 110, 1499-1512.

Bartlett, R., Elrick, M., Wheeley, J. R., Polyak, V., Desrochers, A. \& Asmerom, Y. 2018. Abrupt global-ocean anoxia during the Late Ordovician-early Silurian detected using uranium isotopes of marine carbonates. Proceedings of the National Academy of Sciences, 115, 5896-5901.

Bauert, H., Ainsaar, L., Põldsaar, K. \& Sepp, S. 2014. $\delta^{13} \mathrm{C}$ chemostratigraphy of the Middle and Upper Ordovician 
B. Gul et al.: Latest Ordovician-early Silurian stable isotopes

succession in the Tartu-453 drillcore, southern Estonia, and the significance of the HICE. Estonian Journal of Earth Sciences, 63, 195-200.

Bickert, T., Pätzold, J., Samtleben, C. \& Munnecke, A. 1997. Palaeoenvironmental changes in the Silurian indicated by stable isotopes in brachiopod shells from Gotland, Sweden. Geochimica et Cosmochimica Acta, 61, 2717-2730.

Brand, U., Bitner, M. A., Logan, A., Azmy, K., Crippa, G., Angiolini, L., Colin, P., Griesshaber, E., Harper, E. M., Ruggiero, E. T. \& Häussermann, V. 2019. Brachiopod-based oxygen-isotope thermometer: update and review. Rivista Italiana di Paleontologia e Stratigrafia, 125, 775-787.

Brenchley, P. 1995. Environmental changes associated with the "first strike" of the Late Ordovician mass extinction. Modern Geology, 20, 69-72.

Brenchley, P. J. 2004. End Ordovician Glaciation. In The Great Ordovician Biodiversification Event (Webby, B. D., Paris, F., Droser, M. L. \& Percival, I. G., eds), pp. 81-83. Columbia University Press.

Brenchley, P. \& Marshall, J. 1999. Relative timing of critical events during the late Ordovician mass extinction - new data from Oslo. Acta Universitatis Carolinae Geologica, 1/2, 187-190.

Brenchley, P., Marshall, J., Carden, G., Robertson, D., Long, D., Meidla, T., Hints, L. \& Anderson, T. 1994. Bathymetric and isotopic evidence for a short-lived Late Ordovician glaciation in a greenhouse period. Geology, 22, 295-298.

Brenchley, P., Marshall, J. \& Underwood, C. J. 2001. Do all mass extinctions represent an ecological crisis? Evidence from the Late Ordovician. Geological Journal, 36, 329-340.

Brenchley, P., Carden, G., Hints, L., Kaljo, D., Marshall, J., Martma, T., Meidla, T. \& Nõlvak, J. 2003. High-resolution stable isotope stratigraphy of Upper Ordovician sequences: Constraints on the timing of bioevents and environmental changes associated with mass extinction and glaciation. Geological Society of America Bulletin, 115, 89-104.

Chen, X., Rong, J., Fan, J., Zhan, R., Mitchell, C. E., Harper, D. A., Melchin, M. J., Peng, P. A., Finney, S. C. \& Wang, X. 2006. The Global Boundary Stratotype Section and Point (GSSP) for the base of the Hirnantian Stage (the uppermost of the Ordovician System). Episodes, 29, 183-195.

Cocks, L. R. M. \& Torsvik, T. H. 2005. Baltica from the late Precambrian to mid-Paleozoic times: the gain and loss of a terrane's identity. Earth-Science Reviews, 72, 39-66.

Dronov, A. V., Ainsaar, L., Kaljo, D., Meidla, T., Saadre, T. \& Einasto, R. 2011. Ordovician of Baltoscandia: facies, sequences and sea-level changes. In Ordovician of the World (Gutierrez-Marco, J. C., Rabano, I. \& Garcia-Bellido, D., eds), Cuadernos del Museo Geominero, 14, 143-150.

Finnegan, S., Bergmann, K., Eiler, J. M., Jones, D. S., Fike, D. A., Eisenman, I., Hughes, N. C., Tripati, A. K. \& Fischer, W. W. 2011. The magnitude and duration of Late Ordovician-Early Silurian glaciation. Science, 331, 903-906.

Finnegan, S., Rasmussen, C. M. \& Harper, D. A. 2017. Identifying the most surprising victims of mass extinction events: an example using Late Ordovician brachiopods. Biology Letters, 13, 20170400.

Gorjan, P., Kaiho, K., Fike, D. A. \& Xu, C. 2012. Carbonand sulfur-isotope geochemistry of the Hirnantian (Late Ordovician) Wangjiawan (Riverside) section, South China:
Global correlation and environmental event interpretation. Palaeogeography, Palaeoclimatology, Palaeoecology, 337, 14-22.

Grossman, E. L. 2012. Applying oxygen isotope paleothermometry in deep time. The Paleontological Society Papers, $\mathbf{1 8}$, 39-68.

Grossman, E. L. \& Joachimski, M. M. 2020. Oxygen isotope stratigraphy. In Geologic Time Scale 2020 (Gradstein, F. M., Ogg, J. G., Schmitz, M. D. \& Ogg, G. M., eds), pp. 279307. Elsevier.

Haq, B. U. \& Schutter, S. R. 2008. A chronology of Paleozoic sea-level changes. Science, 322, 64-68.

Harper, D. A., Hammarlund, E. U. \& Rasmussen, C. M. 2014. End Ordovician extinctions: a coincidence of causes. Gondwana Research, 25, 1294-1307.

Harris, M. T., Sheehan, P. M., Ainsaar, L., Hints, L., Männik, P., Nõlvak, J. \& Rubel, M. 2004. Upper Ordovician sequences of western Estonia. Palaeogeography, Palaeoclimatology, Palaeoecology, 210, 135-148.

Herbert, T. D., Peterson, L. C., Lawrence, K. T. \& Liu, Z. 2010. Tropical ocean temperatures over the past 3.5 million years. Science, 328, 1530-1534.

Hints, L. \& Meidla, T. 1997. Porkuni stage. In Geology and Mineral Resources of Estonia (Raukas, A. \& Teedumäe, A., eds), pp. 85-88. Estonian Academy Publishers, Tallinn.

Hints, L., Hints, O., Kaljo, D., Kiipli, T., Männik, P., Nõlvak, J. \& Pärnaste, H. 2010. Hirnantian (latest Ordovician) bio- and chemostratigraphy of the Stirnas-18 core, western Latvia. Estonian Journal of Earth Sciences, 59, 1-24.

Hints, O., Martma, T., Männik, P., Nõlvak, J., Põldvere, A., Shen, Y. \& Viira, V. 2014. New data on Ordovician stable isotope record and conodont biostratigraphy from the Viki reference drill core, Saaremaa Island, western Estonia. GFF, 136, 100-104.

Hood, A. V. S., Planavsky, N. J., Wallace, M. W. \& Wang, X. 2018. The effects of diagenesis on geochemical palaeoredox proxies in sedimentary carbonates. Geochimica et Cosmochimica Acta, 232, 265-287.

Jaanusson, V. 1956. Untersuchungen über den oberordovizischen Lyckholm-Stufenkomplex in Estland. The Bulletin of the Geological Institutions of Uppsala, 36, 369401.

Jacobsen, S. B. \& Kaufman, A. J. 1999. The Sr, C and O isotopic evolution of Neoproterozoic seawater. Chemical Geology, 161, 37-57.

Jones, D. S., Fike, D. A., Finnegan, S., Fischer, W. W., Schrag, D. P. \& McCay, D. 2011. Terminal Ordovician carbon isotope stratigraphy and glacioeustatic sea-level change across Anticosti Island (Québec, Canada). GSA Bulletin, 123, 1645-1664.

Kaljo, D., Heinsalu, H., Mens, K., Puura, I. \& Viira, V. 1988. Cambrian-Ordovician boundary beds at Tõnismägi, Tallinn, North Estonia. Geological Magazine, 125, 457-463.

Kaljo, D., Hints, L., Martma, T. \& Nõlvak, J. 2001. Carbon isotope stratigraphy in the latest Ordovician of Estonia. Chemical Geology, 175, 49-59.

Kim, S.-T. \& O’Neil, J. R. 1997. Equilibrium and nonequilibrium oxygen isotope effects in synthetic carbonates. Geochimica et Cosmochimica Acta, 61, 3461-3475. 
Kump, L., Arthur, M., Patzkowsky, M., Gibbs, M., Pinkus, D. \& Sheehan, P. 1999. A weathering hypothesis for glaciation at high atmospheric $p \mathrm{CO}_{2}$ during the Late Ordovician. Palaeogeography, Palaeoclimatology, Palaeoecology, 152, 173-187.

Lea, D. W., Pak, D. K., Peterson, L. C. \& Hughen, K. H. 2003. Synchroneity of tropical and high-latitude Atlantic temperatures over the last glacial termination. Science, 301, 1631-1634.

Lu, X., Kendall, B., Stein, H. J., Li, C., Hannah, J. L., Gordon, G. W. \& Ebbestad, J. O. R. 2017. Marine redox conditions during deposition of Late Ordovician and Early Silurian organicrich mudrocks in the Siljan ring district, central Sweden. Chemical Geology, 457, 75-94.

Männik, P., Lehnert, O., Nõlvak, J. \& Joachimski, M. M. 2021. Climate changes in the pre-Hirnantian Late Ordovician based on $\delta^{18} \mathrm{O}_{\text {phos }}$ studies from Estonia. Palaeogeography, Palaeoclimatology, Palaeoecology, 569, 110347.

Marshall, J. D., Brenchley, P. J., Mason, P., Wolff, G. A., Astini, R. A., Hints, L. \& Meidla, T. 1997. Global carbon isotopic events associated with mass extinction and glaciation in the late Ordovician. Palaeogeography, Palaeoclimatology, Palaeoecology, 132, 195-210.

Meidla, T., Ainsaar, L. \& Hints, O. 2014. The Ordovician System in Estonia. In 4th Annual Meeting of IGCP 591, Estonia, 1019 June 2014, Abstracts and Field Guide (Bauert, H., Hints, O., Meidla, T. \& Männik, P., eds), pp. 116-122. University of Tartu, Tartu.

Meidla, T., Truuver, K., Tinn, O. \& Ainsaar, L. 2020. Ostracods of the Ordovician-Silurian boundary beds: Jūrmala core (Latvia) and its implications for Baltic stratigraphy. Estonian Journal of Earth Sciences, 69, 233-247.

Munnecke, A., Calner, M., Harper, D. A. \& Servais, T. 2010. Ordovician and Silurian sea-water chemistry, sea level, and climate: A synopsis. Palaeogeography, Palaeoclimatology, Palaeoecology, 296, 389-413.

Puura, V. \& Vaher, R. 1997. Cover structure. In Geology and Mineral Resources of Estonia (Raukas, A. \& Teedumäe, A., eds), pp. 167-177. Estonian Academy Publishers, Tallinn.

Radzevičius, S., Spiridonov, A., Brazauskas, A., Norkus, A., Meidla, T. \& Ainsaar, L. 2014. Upper Wenlock $\delta^{13} \mathrm{C}$ chemostratigraphy, conodont biostratigraphy and palaeoecological dynamics in the Ledai-179 drill core (Eastern Lithuania). Estonian Journal of Earth Sciences, 63, 293-299.

Rasmussen, C. M. O., Ullmann, C. V., Jakobsen, K. G., Lindskog, A., Hansen, J., Hansen, T., Eriksson, M. E., Dronov, A., Frei, R., Korte, C., Nielsen, A. T. \& Harper, D. A. T. 2016. Onset of main Phanerozoic marine radiation sparked by emerging Mid Ordovician icehouse. Scientific Reports, 6, 18884.

Rong, J., Melchin, M., Williams, S. H., Koren, T. N. \& Verniers, J. 2008. Report of the restudy of the defined global stratotype of the base of the Silurian System. Episodes, 31, 315318.

Rõõmusoks, A. 1991. O stratigrafii i faune pogranichnykh sloev pirguskogo i porkuniskogo gorizontov v Severnoj Éstonii [On the stratigraphy and fauna of the boundary beds between the Pirgu and Porkuni stages of North Estonia]. Acta et
Commentationes Universitatis Tartuensis, 934, 23-42 [in Russian, with English summary].

Saltzman, M. M. \& Thomas, E. 2012. Chapter 11 - carbon isotope stratigraphy. In The Geologic Time Scale 2012 (Gradstein, F. M., Ogg, J. G., Schmitz, M. \& Ogg, G., eds), pp. 207-232. Elsevier BV, Amsterdam.

Saltzman, M. R. \& Young, S. A. 2005. Long-lived glaciation in the Late Ordovician? Isotopic and sequence-stratigraphic evidence from western Laurentia. Geology, 33, 109-112.

Samtleben, C., Munnecke, A., Bickert, T. \& Pätzold, J. 2001. Shell succession, assemblage and species dependent effects on the C/O-isotopic composition of brachiopods - examples from the Silurian of Gotland. Chemical Geology, 175, 61-107.

Servais, T., Harper, D. A., Munnecke, A., Owen, A. W. \& Sheehan, P. M. 2009. Understanding the Great Ordovician Biodiversification Event (GOBE): Influences of palaeogeography, palaeoclimate, or palaeoecology. GSA Today, 19(4), 4-10.

Sheehan, P. M. 2001. The late Ordovician mass extinction. Annual Review of Earth and Planetary Sciences, 29, 331-364.

Shields, G. A., Carden, G. A., Veizer, J., Meidla, T., Rong, J.-Y. \& Li, R.-Y. 2003. Sr, C, and O isotope geochemistry of Ordovician brachiopods: A major isotopic event around the Middle-Late Ordovician transition. Geochimica et Cosmochimica Acta, 67, 2005-2025.

Song, H., Wignall, P. B., Song, H., Dai, X. \& Chu, D. 2019. Seawater temperature and dissolved oxygen over the past 500 million years. Journal of Earth Science, 30, 236-243.

Trotter, J. A., Williams, I. S., Barnes, C. R., Lécuyer, C. \& Nicoll, R. S. 2008. Did cooling oceans trigger Ordovician biodiversification? Evidence from conodont thermometry. Science, 321, 550-554.

Trotter, J. A., Williams, I. S., Barnes, C. R., Männik, P. \& Simpson, A. 2016. New conodont $\delta^{18} \mathrm{O}$ records of Silurian climate change: Implications for environmental and biological events. Palaeogeography, Palaeoclimatology, Palaeoecology, 443, 34-48.

Truuver, K., Meidla, T. \& Tinn, O. 2021. End-Ordovician ostracod faunal dynamics in the Baltic Palaeobasin. Estonian Journal of Earth Sciences, 70, 1-38.

Ullmann, C., Frei, R., Korte, C. \& Lüter, C. 2017. Element/Ca, $\mathrm{C}$ and $\mathrm{O}$ isotope ratios in modern brachiopods: Speciesspecific signals of biomineralization. Chemical Geology, 460, 15-24.

Valley, J. W. \& O’Neil, J. R. 1984. Fluid heterogeneity during granulite facies metamorphism in the Adirondacks: stable isotope evidence. Contributions to Mineralogy and Petrology, 85, 158-173.

Veizer, J., Goddéris, Y. \& François, L. M. 2000. Evidence for decoupling of atmospheric $\mathrm{CO}_{2}$ and global climate during the Phanerozoic eon. Nature, 408, 698-701.

Webby, B. D., Paris, F., Droser, M. L. \& Percival, I. G. 2004. The Great Ordovician Biodiversification Event. Columbia University Press, 496 pp.

Young, S. A., Benayoun, E., Kozik, N. P., Hints, O., Martma, T., Bergström, S. M. \& Owens, J. D. 2020. Marine redox variability from Baltica during extinction events in the latest Ordovician-early Silurian. Palaeogeography, Palaeoclimatology, Palaeoecology, 554, 109792. 


\title{
Keskkonnamuutused ja paleotemperatuur Ordoviitsiumi ajastu lõpus ning Siluri alguses Põhja-Eestis süsiniku- ja hapniku isotoopkoostise andmetel
}

\author{
Bilal Gul, Leho Ainsaar ja Tõnu Meidla
}

Käsijalgsete kojad on bioloogilise päritoluga materjal, mida on sageli kasutatud stabiilsete süsiniku- ja hapniku (C, O) isotoopide koosseisu uurimiseks. Kasutasime käesolevas uuringus Baltika paleokontinendi Ordoviitsiumi ajastu lõpu ja Siluri ajastu alguse kogukivimi ja brahhiopoodikodade C- ja O-isotoopide andmeid paleotemperatuuri ja keskkonnamuutuste analüüsimiseks. Kuna tektoonikast ja diageneesist tingitud muutused ei ole selle piirkonna kivimites suured, siis on uuritud kivimmaterjal ja fossiilid enamasti väga hästi säilinud. Proovide $\delta^{13} \mathrm{C}$ ja $\delta^{18} \mathrm{O}$ väärtused jäävad (vastavalt) vahemikku $-1,5 \%$. . . 5\% ja $-2 \%$. .. $-7 \%$ PDB. Karbonaatsetest mineraalidest pärinevate isotoopsignaalide interpreteerimine on keeruline, aga kui need peegeldavad merevee algset isotoopkoostist, siis võiksid kõrged $\delta^{13} \mathrm{C}$ ja $\delta^{18} \mathrm{O}$ väärtused vastata külmematele perioodidele ja vastupidi. Hilis-Ordoviitsiumi mandrijäätumisega seotud Hirnanti süsiniku isotoopsündmus (HICE) on Läänemere piirkonna läbilõigetes hästi jälgitav. HICE algab Põhja-Eesti kogukivimi süsiniku isotoopkõveratel Ärina kihistu (Porkuni lade) ülemises osas väga selge järkjärgulise tõusuna, mis jõuab maksimumini kihistu ülemises osas. Ärina kihistu $\delta^{13} \mathrm{C}$ kõvera tõusuintervall võib vastata Vara-Hirnanti eale. HICE tipule järgneb $\delta^{13} \mathrm{C}$ väärtuste järkjärguline langus Varbola kihistu (Juuru lade) basaalkihtides. Hirnanti-eelsed ning Vara-Hirnanti arvutatud temperatuurid on Velise läbilõike andmetel ligikaudu $30-40{ }^{\circ} \mathrm{C}$ vahemikus, mis on lähedased teistes töödes viidatuile, kuid Männamaa läbilõike andmed näitavad ebarealistlikult kõrgeid temperatuure. Temperatuuri väga suure languse signaal Hirnanti lademest seostub ilmselt kivimites aset leidnud sekundaarsete muutustega madalaveelistes setendites, kuna ületab mitmekordselt hinnangulisi troopilise mere pinnalähedase temperatuuri muutusi Pleistotseenis. Jäätumisjärgset Hilis-Ordoviitsiumi ja Siluri algust iseloomustab teadaolevat globaalset soojenemist markeeriv temperatuuri tõus. Meie uuring näitab, et Ordoviitsiumi lõpu ja Siluri alguse käsijalgsete kojamaterjali $\delta^{18} \mathrm{O}$ väärtused näivad peegeldavat globaalseid temperatuuri muutusi ning kogukivimi $\delta^{18} \mathrm{O}$ muutuse trend on kooskõlas valitseva ettekujutusega jäätumisjärgsest soojenemisest. 